\title{
Students as "co-producers" of education: a proposed model of student socialisation and participation at tertiary institutions
}

\section{The Authors}

\author{
T.G. Kotzé , Lecturer in Marketing, Department of Marketing and Communication \\ Management at the University of Pretoria, Pretoria, South Africa. \\ P.J. du Plessis, Head of Marketing, Department of Marketing and Communication \\ Management at the University of Pretoria, Pretoria, South Africa.
}

\begin{abstract}
Through their participation in an array of learning activities, students "co-produce” their education. At the same time, they also contribute directly to their own satisfaction, quality and value perceptions. How can students be encouraged to fulfil their coproduction roles more effectively? Services marketing researchers have long acknowledged the important participatory role of service customers and have also tested models of the antecedents and consequences of customer socialisation and participation in a range of service settings. Presents a new conceptual model of student socialisation and participation to be tested in the context of higher education.
\end{abstract}

\section{Article Type:}

Research Paper

\section{Keyword(s):}

Customer retention; Students; Tertiary education; Marketing concepts; Social marketing.

\section{Introduction}

Students are not passive recipients of educational services. Through their participation in an array of learning activities, students actually "co-produce” their education (HennigThurau et al., 2001). At the same time, they also contribute directly to their own satisfaction, quality and value perceptions (Bitner et al., 1997).

Services marketing theorists have long acknowledged the important participatory role of service customers and have also investigated the influence of customer participation on the productivity and quality of service encounters, as well as on customers' quality, satisfaction, and value judgments (Lovelock and Young, 1979; Mills and Morris, 1986; 
Kelley et al., 1990; Schneider and Bowen, 1995; Zeithaml and Bitner, 1996; Rodie and Kleine, 2000; Bateson, 2002).

Because students are active participants in the delivery of educational services, some services-marketing theorists argue that they should be regarded as "partial employees" of tertiary institutions (Mills and Morris, 1986). This perspective suggests that students should be actively managed to ensure that their participation facilitates the educational service encounter and its desired outcomes (Kelley et al., 1990). The process of customer organisational socialisation is one means through which this goal can be achieved (Kelley et al., 1990; Hill, 1995).

Experts argue that customer socialisation can be used to help service customers gain an appreciation of specific organisational values, develop the ability to function within a specific service context, understand what is expected of them, and acquire the skills and knowledge necessary to effectively interact with an organisation's employees and with other customers (Zeithaml and Bitner, 1996).

A number of researchers have developed and tested models of the antecedents and consequences of customer socialisation and participation in service settings. These models were tested in contexts ranging from financial services (Kelley et al., 1992; Govender, 1998) and grocery retailing (Bettencourt, 1997) to charitable organisations (Cermak et al., 1994; Claycomb et al., 2001).

However, despite the importance of student participation in the provision of educational services, similar models have not yet been tested in the context of tertiary education. This may be due to the fact that the relevance of services-marketing theory for tertiary institutions has only recently been acknowledged (Mazzarol and Soutar, 1999; Hill, 1995).

This article has three objectives, namely to:

(1) summarise existing knowledge on customer participation and socialisation in service organisations with specific application to tertiary institutions;

(2) review existing models of the antecedents and consequences of customer socialisation and participation; and

(3) develop a new conceptual model of student socialisation and participation to be tested in a future study.

The article, which will specifically focus on the participatory role of undergraduate students, is structured as follows. First, current theory on customer participation in service settings is summarised. This is followed by a review of the literature on student participation. Next, the socialisation of service customers is considered and this is followed by a review of the literature on the socialisation of undergraduate students. In the final section, a new conceptual model is presented based on 18 propositions about the 
relationship between selected antecedents and consequences of student socialisation and participation in the context of tertiary education.

\section{Customer participation in service settings}

One unique feature of services, when compared with tangible goods, is that services are produced while being consumed. This implies that service customers are often present during service delivery and even actively involved in the production of the services they receive (Mazzarol and Soutar, 1999). Services-marketing researchers have considered customer participation from a number of theoretical perspectives, including script theory (Bateson, 2002), role theory (Solomon et al., 1985; Mills and Morris, 1986), customer socialisation (Kelley et al., 1990), social exchange theory (Bettencourt, 1997), and quality improvement (Lengnick-Hall, 1996).

While the level of required customer participation differs across service settings (Zeithaml and Bitner, 1996), active participation is unavoidable in the case of human service organisations such as universities and other tertiary institutions (Lengnick-Hall et al., 2000). Customers are an integral part of the service delivery system in these settings and also the primary products or vehicles for demonstrating that the desired service outcomes have been achieved (Lengnick-Hall et al., 2000). Unless customers perform their "co-production" roles effectively, the desired outcomes will not be realised.

Figure 1 highlights a number of factors that have to be managed in order to ensure effective customer participation in service production and delivery.

Customer participation may take different forms. Rodie and Kleine (2000) note, for example, that customers can supply three types of resources during a service encounter, namely:

(1) Mental inputs - including information and mental effort (e.g. students exert substantial mental effort when preparing a research paper).

(2) Physical inputs - including making tangible assets available that are needed for service delivery or performing physical labour (e.g. students conducting a chemistry experiment perform physical labour).

(3) Emotional inputs - such as behaving patiently or pleasantly towards service employees (e.g. students facilitate service delivery when they are courteous towards lecturers and/or administrative staff). 
Figure 1 Factors affecting effective customer participation in service settings

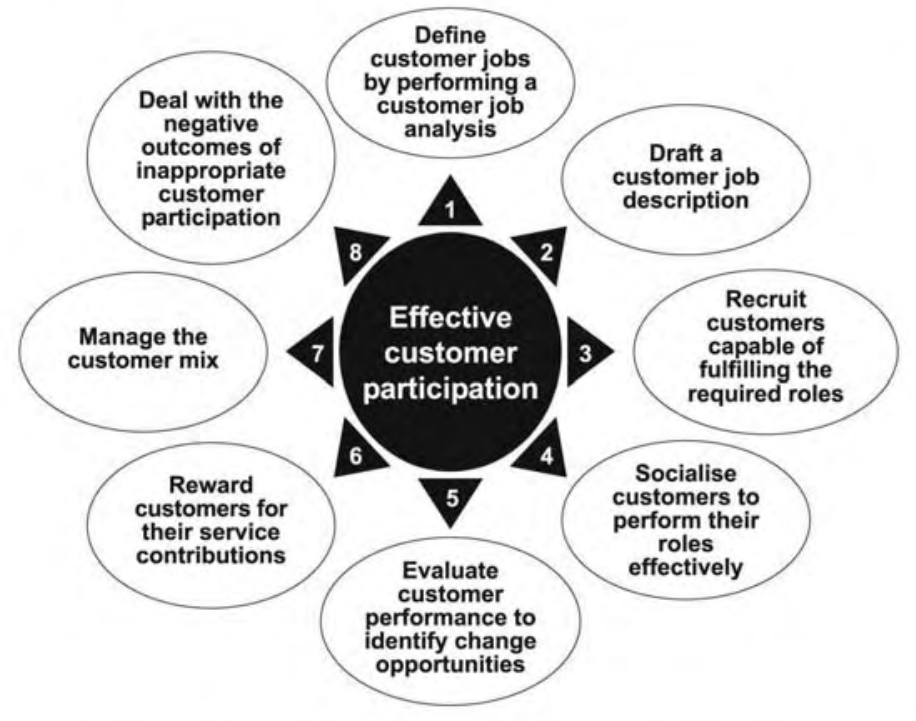

Source: Adapted from Zeithaml and Bitner (1996) and Schneider and Bowen (1995)

Claycomb et al. (2001) discuss three different levels of customer participation, as depicted in Table I.

Table I Levels of customer participation across different services

$\begin{aligned} & \text { Level of } \\ & \text { participation }\end{aligned}$
$\begin{array}{ll}\text { Low } & \text { Forms of participation } \\ \text { Moderate } \quad \text { that is required is the customer's physical presence or attendance. Employees of the service organisation do all the service } \\ \text { production and delivery work } \\ \text { The customer participates by providing information to or about the organisation. The customer acts as a consultant, quality inspector } \\ \text { and reporter to others by: } \\ \text { - providing information to the organisation about both good and bad service delivery; } \\ \text { - offering innovative ideas; and } \\ \text { - communicating in a positive or negative way with other potential and existing customers about the service or the organisation } \\ \text { The customer works in partnership with the service organisation to help assess the need for service, customise the design and } \\ \text { delivery of the service, and produce a portion or all of the service for him/herself. The customer can, therefore, be regarded as } \\ \text { a co-producer, co-creator or partial employee who contributes effort, time or other resources to the service production process }\end{array}$
Source: Adapted from Claycomb et al. (2001)

The educational services provided by tertiary institutions clearly fall into the "high customer participation" category. A number of authors support this view and accentuate the long-term nature of educational services, the need for extensive customer socialisation and "co-production" in this context, and the advantages for students when "active learning" is promoted (Wright et al., 1994; Armstrong, 1995; Howard and Henney, 1998; Hennig-Thurau et al., 2001). 
Other researchers have operationalised customer participation by:

- focusing on the technical and functional quality of customer inputs (Kelley et al., 1992);

- investigating customers' quality assurance behaviours during service encounters (Kellogg et al., 1997); and

- distinguishing between required and voluntary customer behaviours (Bettencourt, 1997).

While writers have different views on the nature and form of customer participation, it is generally accepted that effective participation depends on three factors, namely customers' role clarity, ability, and motivation (Schneider and Bowen, 1995; LengnickHall, 1996; Lengnick-Hall et al., 2000; Rodie and Kleine, 2000). These factors are discussed in greater detail below:

(1) Role clarity. Customers must know exactly what they are expected to do and how they are expected to perform during a service encounter. The specific roles, contributions, boundaries and avenues for customer participation should be clear, familiar and consistent (Lengnick-Hall, 1996). Rodie and Kleine (2000) mention four sources of role clarity, namely a customer's own experience with a particular service provider, a customer's experiences with the services provided by an organisation's direct competitors, a customer's experiences with similar service contexts, and the behaviour of other customers who are present in the service setting. Service organisations can enhance customers' role clarity through organisational socialisation (Rodie and Kleine, 2000). Empirical research by Govender (1998) suggests a negative relationship between organisational socialisation and customers' perceived role ambiguity and role conflict.

(2) Ability. Effective participation also requires customers who are capable of making useful and timely contributions during service delivery (Lengnick-Hall et al., 2000). Rodie and Kleine (2000) provide a very broad definition of ability, which includes “... all pertinent resources such as knowledge, skill, experience, energy, effort, money, or time”. In their view, role clarity is one aspect of knowledge that contributes to ability. Service organisations, such as universities and other tertiary institutions, can use a combination of selection methods, communication initiatives and training programmes to ensure that customers have the necessary abilities to act as effective service participants (Schneider and Bowen, 1995).

(3) Motivation. Customers must also be motivated to participate in and during service delivery (Lengnick-Hall et al., 2000). Schneider and Bowen (1995) argue that service customers are primarily motivated by self-interest. When faced with self-service or co-production service tasks, customers must feel that there is some intrinsic or extrinsic reward involved. Rodie and Kleine (2000) mention three types of benefits that motivate customer participation, namely, efficiency in the service process, efficacy of the service outcome, and psychological benefits (e.g. novelty, enjoyment, and increased perceived control). Customers may not realise the benefits of 
participation unless the service organisation explicitly communicates these benefits to them (Zeithaml and Bitner, 1996). This suggests that socialisation methods can be used to increase customer motivation to actively participate in service production and delivery. Empirical research by Kelley et al. (1992) discovered a significant positive relationship between organisational socialisation and customers' "motivational direction”.

The above discussion suggests that socialisation tactics can be used to improve customers' role clarity, their ability to effectively participate during service production and their motivation to do so. Increased role clarity, ability and motivation will, in turn, influence customers' willingness to participate in service delivery (Rodie and Kleine, 2000). The following are therefore proposed:

$P 1$. Students' role clarity is positively related to their . participation in teaching/learning activities.

P2. Students' perceived ability or competence is positively related . to their participation in teaching/learning activities.

P3. Students' motivation is positively related to their . participation in teaching/learning activities.

Effective customer participation can benefit both the service organisation and its customers in specific ways (Cermak et al., 1994; Schneider and Bowen, 1995; Rodie and Kleine, 2000; Claycomb et al., 2001). However, customer participation can be problematic. First, customer involvement in service delivery often raises the level of uncertainty in service production systems. Second, despite opportunities for selection and training, service organisations do not have the same degree of control over customers as they have over normal employees. Third, customers may abdicate their co-production roles. Some customers prefer not to participate actively in service production (LengnickHall, 1996). Managing customer participation can, therefore, be quite a challenge.

Despite these problems, studies provide empirical support for a number of positive outcomes of customer participation. Research findings indicate that customer participation is positively associated with:

- customers' perceptions of service quality (Cermak et al., 1994; Claycomb et al., 2001);

- customers' perception of the organisational climate for service (i.e. the organisation's service orientation) (Kelley et al., 1992);

- customer satisfaction (Cermak et al., 1994; Kelley et al., 1992);

- customers' behavioural intentions with regard to repeat purchasing and positive word-of-mouth communication (Cermak et al., 1994), which are often used as proxy indicators of customer loyalty (Bettencourt, 1997; Hennig-Thurau et al., 2001); and 
- the level of beneficial outcomes that customers perceive (Lengnick-Hall et al., 2000).

Based on these findings, the following propositions are suggested:

P4. Students' participation in teaching/learning activities is . positively related to students' perceptions of the quality of teaching services provided.

P5. Students' participation in teaching/learning activities is . positively related to students' overall satisfaction with the teaching services provided.

P6. Students' participation in teaching/learning activities is . positively related to students' loyalty to the tertiary institution (measured as behavioural intentions).

Bitner et al. (1997) also point out that customers who participate in service delivery frequently blame themselves (at least partially) when things go wrong. If customers believe that they are partially to blame for service failures, they will be less dissatisfied with the service provider than when they believe that the provider is solely responsible and could have avoided the problem:

Customer participation in service delivery raises a number of questions for management practice and research (Bitner et al., 1997; Rodie and Kleine, 2000). These questions, which are also relevant for tertiary institutions, concern the following:

- What types of information and education should an organisation share with its customers in order to prepare them for their roles as "partial employees" and "coproducers" of service?

- Which methods of socialisation, customer education and information dissemination are most effective?

- How can customers be rewarded for effective participation?

- How can an organisation monitor the quality of customer participation and provide feedback to guide improvements and offer encouragement?

- Which tools can organisations use to clarify customer role expectations?

- What is the influence of participation levels on customer evaluations (i.e. perceived quality, satisfaction, value) and post-purchase behaviours such as repurchase and word-of-mouth communications?

- Under which circumstances are participating customers more likely to assume blame for service failures?

- Can markets be segmented on the basis of customers' willingness to participate in service delivery?

\section{Student participation}

While the aforementioned principles regarding customer participation can be applied to students, it is also necessary to consider specific research on student participation. 
Tertiary institutions provide a range of services and facilities to students, including teaching, administrative services, computing facilities, library services, on-campus retailing, career and placement services, counselling/welfare services, health services, accommodation, catering, and sport and recreational services (Hill, 1995). Students play a participatory role when using most of these services or facilities.

This article, however, focuses attention on student participation in the teaching services provided by a tertiary institution. Even in this context, student participation can take different forms (see Figure 2).

Figure 2 Forms of student participation in teaching services

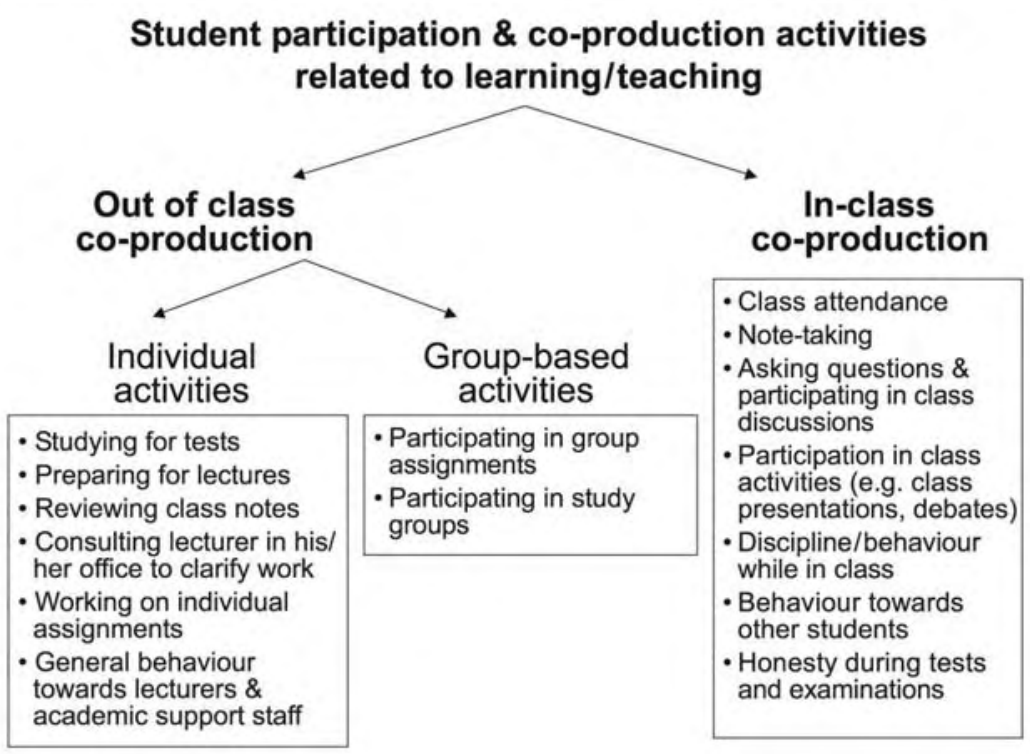

However, with the exception of oral participation, the issue of student participation has not received much attention in the literature. In order to stimulate effective student participation, educators need to understand the factors that shape students' expectations and perceptions regarding participation, as well as their "co-production" behaviours for the different forms of participation listed in Figure 2.

In this regard, Niehoff et al. (2001) explain that students develop expectations about the behaviours and practices that lecturers should exhibit in the classroom as well as about their own classroom obligations (i.e. regarding class participation, preparing assignments for class, and the appropriateness of questioning the lecturer in class). Unfortunately, the nature and formation of these expectations are not clearly understood. 
Students' oral participation in the university classroom has recently come under the spotlight. Researchers contend that only a small percentage of students participate orally in class (Nunn, 1996; Howard and Henney, 1998; Fritschner, 2000). Students offer a range of reasons for (non-)participation, which differ across age, student gender and instructor gender categories (Howard and Henney, 1998).

Research findings also indicate that the level and nature of students' oral participation are affected by many variables, which Fassinger (1995) has divided into three categories, namely:

(1) Class traits - which include class size (Howard and Henney, 1998), course level (Fritschner, 2000), frequency of class meetings (Howard and Henney, 1998), class time (Howard and Henney, 1998), week in the semester (Howard and Henney, 1998), peer-based interaction norms (Fassinger, 1995) and emotional climate (Fassinger, 1995).

(2) Student traits - which include student gender (Fritschner, 2000), student age (Howard and Henney, 1998), students' confidence (Fassinger, 1995) and their interest in the subject (Fassinger, 1995).

(3) Lecturer traits - which include instructor gender (Howard and Henney, 1998), teaching techniques used (Nunn, 1996), instructors' oral and non-oral communication behaviours (Fritschner, 2000) and grading practices (Fassinger, 1995).

Communication researchers further suggest that individual students' classroom communication apprehension (Neer, 1987; Myers and Rocca, 2001) and perceptions of classroom climate (Rosenfeld and Jarrard, 1985) should also be considered.

According to Fritschner (2000), six levels of student participation can be distinguished in undergraduate classrooms:

(1) Level one: students attend class and stay awake/pay attention.

(2) Level two: students attend class, take notes and complete assignments.

(3) Level three: students write papers that are thoughtful and reflective.

(4) Level four: students ask questions in class, make comments and provide inputs for class discussions.

(5) Level five: students do additional research or come to class with additional questions.

(6) Level six: students deliver oral presentations (i.e. they become teachers themselves). 
She also established that students engage in specific behaviours to signal their discontent with others who talk "too much" in class. These findings clearly indicate that students' oral classroom participation is not a simplistic issue (Fritschner, 2000).

Finally, research by Sanders et al. (2000) as well as by Karns (1993) indicates that undergraduate students have definite preferences for specific learning and assessment techniques, as well as perceptions about the effectiveness thereof. These findings suggest that students may prefer certain forms of participation and co-production.

\section{Socialisation of service customers}

Customer participation does not happen automatically, but depends on customers' role clarity, ability and motivation. Many authors argue that customers need to be socialised in order to effectively fulfil their participation roles (Kelley et al., 1990; Zeithaml and Bitner, 1996; Govender, 1998).

Kelley et al. (1992) describe organisational socialisation as:

... the process by which an individual adapts to and comes to appreciate the values, norms and required behavior patterns of an organization.

They point out that customer organisational socialisation can be used to provide service customers with organisationally specific behavioural guidelines to direct their participation in service production and delivery.

In order to stimulate more effective customer participation, service organisations need to address all three of the requirements for effective customer participation - role clarity, ability, and motivation - in their customer socialisation efforts (Schneider and Bowen, 1995; Rodie and Kleine, 2000; Lengnick-Hall et al., 2000).

The literature on the socialisation of service customers highlights a number of important issues:

(1) Customer socialisation is not a one-way process. It provides managers with a means of communicating to customers what they desire in the service encounter, while also determining what customers are willing and able to bring to the encounter (Kelley et al., 1990).

(2) The organisational socialisation of service customers may elicit a range of responses from individuals with regard to their understanding of organisational values, norms and expectations (Kelley et al., 1990). Customer socialisation should, therefore, be seen as a process in which degrees of success can be assessed. Kelley et al. (1992) have developed a scale to measure the "level” of organisational socialisation achieved by service customers. 
(3) Several mechanisms exist by means of which service customers can be socialised. These include:

- Formal orientation programmes (e.g. induction programmes for first-year students).

- Written literature provided to customers (e.g. study guides and course outlines).

- Directional cues and signage in the service environment (e.g. notices indicating where study assignments should be submitted).

- Learning from employees (e.g. a lecturer explaining the requirements for a course in class).

- Reinforcement and punishment (e.g. deduction of marks, if assignments are handed in late).

- Learning from other customers (e.g. mentorship programmes or informal socialisation through observation of the actions of other students).

- Realistic service previews (e.g. detailed course overviews provided by a lecturer in an introductory lecture).

- Service level agreements[1] between customers and the service provider, outlining the rights, duties and obligations of all parties (Hill, 1995; Rodie and Kleine, 2000).

(4) Customers are likely to perform their service production roles more effectively if they are rewarded for doing so. Service organisations should consider the intrinsic and extrinsic rewards that customers may experience by participating in service delivery. If the intrinsic rewards offered are not sufficient to motivate the required customer performance, an organisation will have to consider what extrinsic rewards it could provide (Schneider and Bowen, 1995).

(5) Experts point out that not all customers may want to participate in service production. Further, different customer segments are motivated by different types of rewards (Zeithaml and Bitner, 1996).

(6) If customers are not effectively socialised, they may behave inappropriately during service encounters. The following inappropriate behaviours could result in negative outcomes for the organisation:

- Customers who do not understand the service system may slow down the service process and negatively affect their own and other customers' service outcomes.

- If customers do not perform their service roles effectively, it may not be possible for employees to ensure the level of quality, satisfaction and value promised by the organisation.

- If customers are frustrated because of their own inadequacies and incompetence, they may take this out on service employees who are likely to suffer emotionally and be less able to deliver quality service. Experts agree that well-managed service encounters are ones in which both customers and employees are satisfied (Kelley et al., 1992; Zeithaml and Bitner, 1996; Kellogg et al., 1997). 
(7) Customer socialisation often involves efforts directed at the management of customer expectations. Kelley et al. (1992) argue that, in service transactions that include customers as resource contributors, there are mutual expectations involving a pattern of rights, privileges and obligations. Customers' expectations in terms of these three issues may be ill-defined and unrealistic (Hill, 1995). Service organisations, including institutions of higher learning, can manage expectations through socialisation and communication efforts. However, in order to effectively manage customer expectations, service organisations need to:

- understand the nature of customer expectations, how these are formed and how they change over time as the customer becomes more familiar with the organisation;

- continuously inform customers of what is and what is not possible in terms of service delivery and outline the reasons why; and

- address customers' self-perceived service roles and their perceptions of situational factors that influence the service encounter (Hill, 1995).

Service marketing researchers have considered the consequences of organisational socialisation when directed at service customers. Empirical research by Kelley et al. (1992) indicates that the level of organisational socialisation achieved by service customers is positively related to their:

- perceptions of the organisational climate for service (i.e. the organisation's perceived service orientation);

- perceptions of service quality;

- satisfaction with the services provided; and

- motivational direction, which focuses on the “... appropriateness of the particular activities into which effort is directed and maintained" (Katerberg and Blau in Kelley et al., 1990).

Research by Govender (1998) suggests that there are a number of additional outcomes of customer organisational socialisation. He specifically focused on the influence of formal and informal socialisation tactics.

In the context of customer socialisation, formal socialisation refers to tactics and strategies which a service organisation adopts to ".. actively and formally train, orientate and indoctrinate ...” its customers. Formal socialisation takes the choice away from customers by providing them with organisationally accepted socialising agents (Govender, 1998).

Informal socialisation, on the other hand, refers to all incidental methods by which customers become acquainted with their roles and with the organisation (e.g. a customer overhears a service agent directing another customer or "mimics" the behaviour of other customers) (Govender, 1998).

Govender (1998) specifically found that formal and informal socialisation are both: 
- positively associated with customers’ perceptions of the organisational climate for service;

- $\quad$ positively associated with customers' overall service quality perceptions, as well as their perceptions of employee service quality;

- negatively associated with customers’ role ambiguity; and

- negatively associated with customers' role conflict.

The following propositions are based on the previous discussion:

P7. Organisational socialisation of students is positively related . to their perceptions of the quality of the teaching services provided.

P8. Organisational socialisation of students is positively related . to their overall satisfaction with the teaching services provided.

P9. Organisational socialisation of students is positively related . to their role clarity.

P10. Organisational socialisation of students is positively related . to their perceived ability/competence

P11. Organisational socialisation of students is positively related . to their motivation.

Kelley et al. (1990) also suggested a positive association between customer organisational socialisation and the customer's commitment to a service organisation. These authors argued that organisational socialisation leads customers to a better understanding of and stronger identification with organisational goals and values. As customers come to accept organisational goals and values through the socialisation process, they become more committed to the organisation. The following is therefore proposed:

P12. Organisational socialisation of students is positively related . to their affective commitment to the tertiary institution.

Next, attention will be focused on specific research related to the socialisation of undergraduate students.

\section{Socialisation of undergraduate students}

The socialisation of undergraduate students has recently come under scrutiny because of concerns over the relatively high levels of student attrition (Cook and Leckey, 1999; Johnston, 2001; Pitkethly and Prosser, 2001), as well as the need to prepare students for new teaching and learning approaches (Taylor, 2000).

A review of the recent literature on student socialisation highlights a number of important issues: 
(1) year students face a number of challenges in making the adjustment from high school to tertiary education. They are expected to learn challenging material, be capable of independent thought, and adjust to different teaching styles as well as to an expanded social environment (Johnston, 2001). A high proportion of first-years fail to meet these challenges because of adjustment or environmental factors, rather than because of intellectual difficulties (Pitkethly and Prosser, 2001).

(2) Cook and Leckey (1999) found that many students arrive at tertiary institutions with unrealistic views about the amount of work expected, the type of learning and studying they will encounter, and the size of classes in which they will be taught. Further, many first-years also enter higher education without having taken responsibility for their own learning. These authors argue that tertiary institutions have to be proactive “... in the conscious development of a set of study skills appropriate for a tertiary environment”.

(3) In addition to the general need to socialise new students extensively, other needs may arise as a result of cultural factors. Research by Niehoff et al. (2001) suggests that students from different cultural backgrounds may have differing expectations with regard to classroom practices, including aspects such as group activities, group assignments, class informality, mandatory class attendance, and the freedom to question grades or debate with the lecturer. Many tertiary institutions have recognised the need to help new students adjust academically and socially to the new learning environment, as well as to their roles as students. Pitkethly and Prosser (2001) and Taylor (2000), for example, report on extensive formal initiatives for the socialisation of first-year students at La Trobe and Griffith Universities respectively. These socialisation initiatives aim to achieve a number of objectives, namely to:

- familiarise students with the university;

- develop students' sense of purpose and direction (i.e. their motivation);

- facilitate students' engagement in university life;

- promote and enhance students’ learning; and

- modify students' expectations of how they will be taught and the roles they will be asked to play.

(4) Socialisation, however, is not a once-off activity limited to new first-year students, but a continuing process. Bogler and Somech (2002) suggest that student socialisation takes place by formal and informal means involving organised activities (e.g. first-year orientation programmes), as well as contact between students and lecturers, and between students and their peers. They also argue that students use different socialisation tactics - scholastic, instrumental or collegiate socialisation that correlate with their motives to study.

(5) Johnston (2001) suggests that lecturers shape the learning approach of students through their approach to teaching. She points out that most lecturers at tertiary institutions want their students to be able to “... analyse, assess, think critically, describe, apply ideas and change their interpretations of the world, in other words, 
adopt a deeper approach to learning”. However, in order to achieve these goals, the educational environment must be appropriate and teaching must be aimed at these goals. Johnston (2001) argues that students can be encouraged to take a deep approach to learning through “... clearly stated academic expectations, an emphasis on meaning and relevance, teaching and assessment methods that foster active and long-term engagement with learning tasks, appropriate workloads that encourage reading for understanding, a degree of choice in the areas of what and how to study, and teachers who are enthusiastic, committed and have an interest in and knowledge of their subject”.

(6) Finally, Hoffman and Kelley (1991) adopt a services-marketing perspective on the socialisation of students. They argue that the notion of the customer as a "partial employee", and therefore also the process of organisational socialisation, applies to the role that students play in the education service encounter. These authors tested Feldman's (1976) model of organisational socialisation on a sample of undergraduate marketing students. Their findings indicate that it is important for educators to act as socialisation agents in the classroom, especially with regard to congruence and role definition.

The aforementioned review suggests that the socialisation of students is an important, but complex and continuous process, which requires:

- an in-depth understanding of students' expectations, needs and experiences, as well as of the factors and processes that shape these;

- clarity on the specific learning/teaching approach and climate that a lecturer or academic department wishes to establish in the classroom; and

- comprehensive and co-ordinated socialisation strategies for creating and sustaining the desired learning/teaching approach and classroom climate.

Existing models of the antecedents and consequences of customer socialisation and participation will be described next. This discussion will provide a basis for the introduction of a new model of the antecedents and consequences of student socialisation and participation.

\section{Models of the antecedents and consequences of customer socialisation and participation in service organisations}

A number of models of the antecedents and consequences of customer socialisation and participation in service settings have been reported in the services-marketing literature. These models, which differ in terms of the constructs involved, relationships tested, measures used, statistical methods employed, and the contexts in which the models were evaluated, are summarised in Figure 3. 
Figure $3 \mathrm{~A}$ new model of the antecedents and consequences of student socialisation and participation

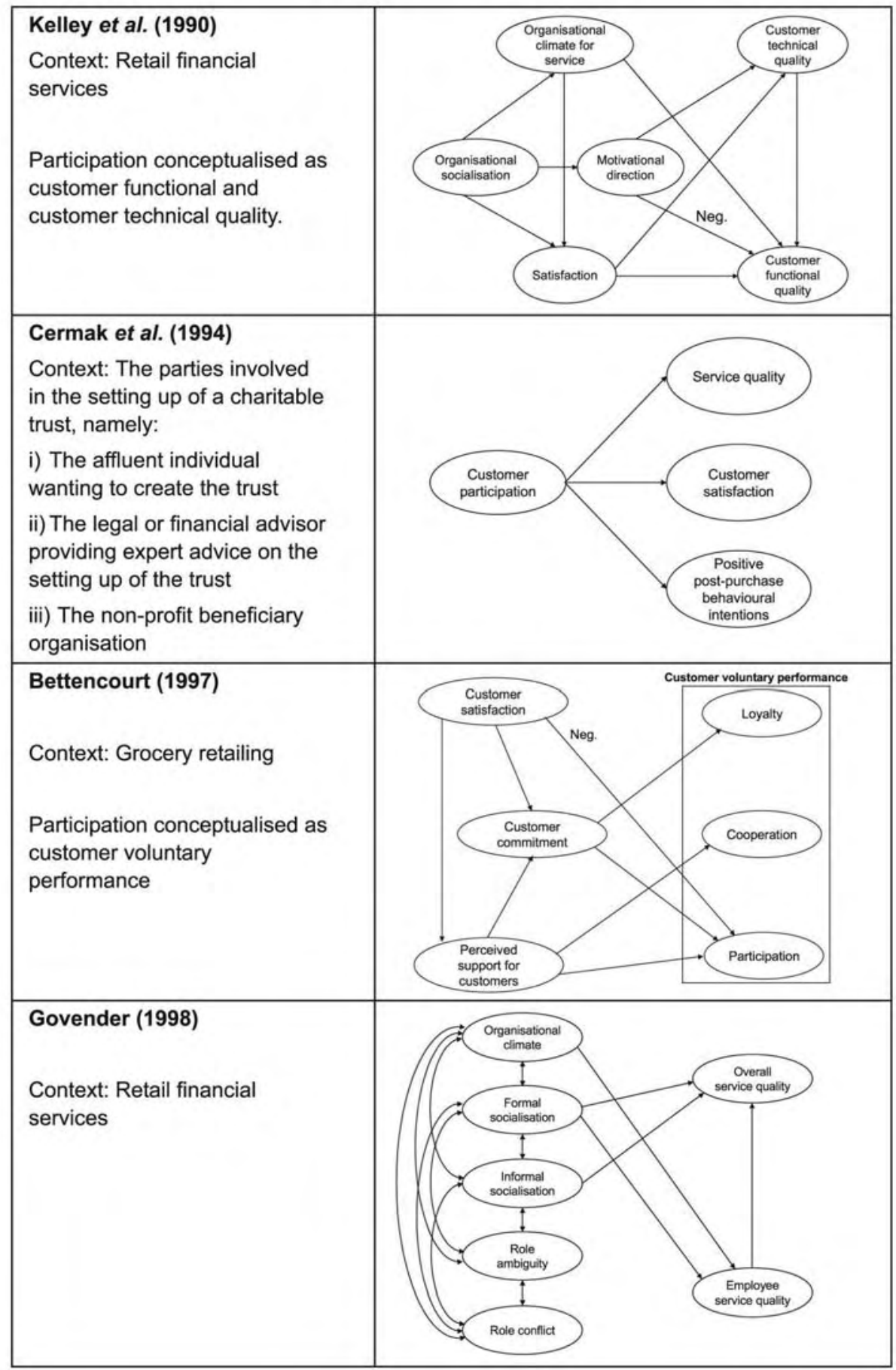


Figure 3 indicates the constructs included in each model, the significant parameters or correlations found and the context in which each model was tested. All relationships are positive unless indicated otherwise.

In addition to the four models presented in Figure 3, empirical research by Claycomb et al. (2001) and Hennig-Thurau et al. (2001) was also important in the development of the new model proposed in this article. Together these six studies suggest a number of additional propositions.

First, Bettencourt (1997) found a positive relationship between customers’ affective commitment to a service organisation and their participation, which he defined as:

... customer behaviors indicating active and responsible involvement in the governance and development of the organization.

Bettencourt's (1997) operationalisation of participation focused on customer complaints and suggestions for service improvements. Bettencourt (1997) also found a positive relationship between customer satisfaction and affective commitment. This finding is consistent with other research (Wetzels et al., 1998). Based on these findings, the following propositions are suggested:

P13. Students' . participation in teaching/learning activities is positively related to their affective commitment to the tertiary institution.

P14. Students' overall satisfaction is positively related to their . affective commitment to the tertiary institution.

Second, Hennig-Thurau et al. (2001) tested a relationship quality-based model of student loyalty. The authors found positive relationships between students' perceptions of the quality of teaching services, on the one hand, and their affective commitment and loyalty towards the tertiary institution, on the other. In addition, the authors also found a positive relationship between students' affective commitment and their loyalty to a tertiary institution. Similarly, Bettencourt (1997) found a positive relationship between customer commitment and loyalty in the context of grocery retailing. Based on these findings, it is proposed that:

P15. Students' perceptions of the quality of teaching services . provided are positively related to their affective commitment to the tertiary institution.

P16. Students' perceptions of the quality of teaching services . provided are positively related to their loyalty to the tertiary institution.

P17. Students' affective commitment to the tertiary institution is . positively related to their loyalty towards the institution. 
Third, research by Cermak et al. (1994) suggests a positive relationship between customer satisfaction and loyalty (measured as behavioural intentions). Cronin et al. (2000) recently reported similar findings. Based on these findings, the following proposition is put forward:

P18. Students' overall satisfaction is positively related to their . loyalty to the tertiary institution.

The 18 propositions will now be combined into a new model of the antecedents and consequences of student participation and socialisation.

\section{A new model of the antecedents and consequences of students' socialisation and participation}

The new proposed model is illustrated in Figure 4.

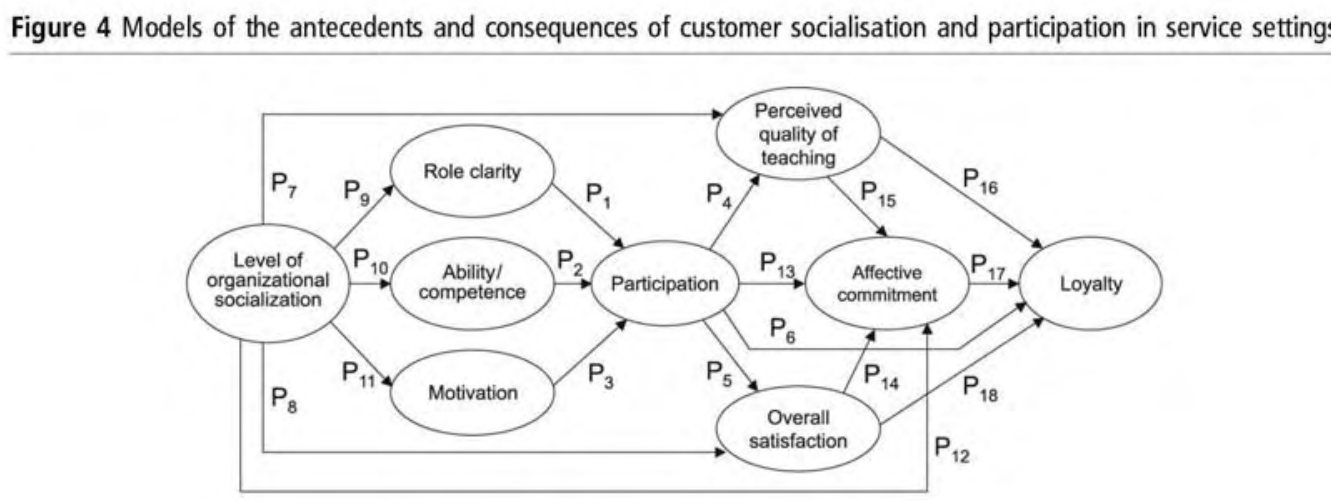

Note: P denotes proposition. All the proposed relationships are positive

In order to test the proposed model, a number of research challenges have to be considered.

First, models, such as the one proposed in Figure 4, are generally tested using structural equation modelling (SEM). Experts regard SEM as most useful for theory development and testing (Steenkamp and Baumgartner, 2000), but point out that there are many pitfalls that can make SEM a “... dangerous tool in the hands of inexperienced users” (Baumgartner and Homburg, 1996).

The question of causal direction is one important issue to consider in SEM models. In this regard, Netemeyer (2001) states:

In a correlational framework, particularly where the data were collected cross-sectionally ... it is next to impossible to confidently infer that one construct causes another. 
He also indicates that switching the direction of the relationship between two constructs will, in many cases, not affect the fit of the model or alter the parameter estimate of association between two constructs. Consequently, with cross-sectional SEM data:

... one can safely argue that a model is consistent with a set of causal relations, but the exact directional association cannot be demonstrated (Netemeyer, 2001).

Longitudinal research designs, while still not adequate for confident causal inferences, provide stronger evidence for a temporal sequence between constructs in a model (Bentler, 2001; Netemeyer, 2001). Since the proposed model suggests that customer organisational socialisation "leads to" increased participation, which in turn "causes" more positive customer evaluations, commitment and loyalty, a longitudinal research design may have to be considered.

The fact that student participation can take many forms and is influenced by various factors poses a second major research challenge. It may be necessary to focus attention on a specific form of student participation (such as oral participation in the classroom) and expand the proposed model by including additional constructs that are relevant to the specific form of student participation being considered (e.g. students' communication apprehension and perceptions of the classroom climate in the case of oral participation).

Third, it should be noted that no single model could include all the constructs that influence a specific type of behaviour and its outcomes, as well as all the relationships between the included constructs. In this regard, Morgan and Hunt (1994) emphasise the importance of model parsimony. While there is theoretical support for the inclusion of additional constructs in the proposed model (e.g. trust), as well as for the testing of additional structural relationships (e.g. perceived quality of teaching - overall student satisfaction), it is contended that the model includes the most pertinent constructs suggested by services marketing theory and available empirical research.

Finally, reliable and valid measurement scales that are appropriate for the context of higher education will have to be found or developed to operationalise each of the constructs in the proposed model. The following measurement scales in Table II may be used or adapted for this purpose. 
Table II Proposed measurement scales to be used in future study

\begin{tabular}{|c|c|}
\hline Construct & Proposed measurement scale \\
\hline Role clarity & $\begin{array}{l}\text { An adaptation of the scale used by Govender (1998) or the well-known scale of Rizzo } \\
\text { et al. (1970) }\end{array}$ \\
\hline Ability-competence & The Self-Perception Profile for College Students (Neemann and Harter, 1986) \\
\hline Student motivation & $\begin{array}{l}\text { Appropriate items from the "Motivated strategies for learning questionnaire" (Pintrich and Smith, } \\
\text { 1993) or the "Academic motivation scale" (Vallerand et al., 1992) }\end{array}$ \\
\hline Perceived quality of teaching & The course experience questionnaire (Ramsden, 1991; Wilson and Lizzio, 1997) \\
\hline Overall satisfaction & $\begin{array}{l}\text { An adaptation of the scale used by Bettencourt (1997). Single-item student satisfaction measures } \\
\text { have been used by Lizzio et al. (2002) and Palihawadana and Holmes (1999). These can also } \\
\text { be considered }\end{array}$ \\
\hline
\end{tabular}

Howard and Henney (1998) caution against the use of surveys to investigate students' classroom participation and indicate that:

... what students say in surveys and how they actually behave in the classroom can be two very different things.

However, since data are required at the individual respondent level, surveys may be the only practical data collection method for testing the model.

\section{Conclusion}

Learning is not a spectator sport. Students do not learn much just by sitting in classes listening to teachers, memorizing pre-packaged assignments, and spitting out answers. They must talk about what they are learning, write about it, relate it to past experiences, apply it to their daily lives. They must make what they learn part of themselves (Chickering and Gamson in Nunn, 1996).

As the above quotation suggests, active student participation is an essential ingredient in ensuring process, as well as outcome quality in higher education. Students, especially undergraduates, need to be socialised to realise that they are not passive recipients of education. They need to understand that they, in fact, "co-produce" their own educational experiences and related outcomes.

Bringing students to this realisation and encouraging them to capitalise on the opportunities for growth offered by tertiary institutions will remain a major challenge for educators.

It is believed that services marketing theory, along with research in the fields of education, communication, sociology and psychology, can help educators develop more effective approaches to the stimulation of student participation and "active learning". 
This article presented a conceptual model of the relationship between selected antecedents and consequences of customer socialisation and participation, based on available theory and empirical research findings in the field of services marketing.

A number of authors have expressed concern over the application of marketing principles to higher education (Driscoll and Wicks, 1998; Schwartzman, 1995). At the root of this concern is the fear of a power shift towards the student, as encapsulated in the adage that the "customer is always right” (Scott, 1999).

It was indicated that, contrary to popular belief, marketing does not see the customer as a passive demander whose every fleeting whim has to be satisfied at all costs. Servicesmarketing theory emphasises the important participative and co-production roles of customers and also considers how customers can be socialised to fulfil these roles more effectively.

Such an application of services marketing principles to student participation clearly indicates that tertiary education "... remains a service as capable of treatment as any other in terms of marketing theory" (Mazzarol and Soutar, 1999). It also highlights a major quality-related challenge for educators.

\section{Note}

1. The University of Liverpool's student charter is a good example of such a "service level agreement" and can be found on the Internet at: www.liv.ac.uk/tqsd/Charter/studentcharterbackground.htm

\section{References}

Armstrong, J.S. (1995), "The devil's advocate responds to an MBA student's claim that research harms learning", Journal of Marketing, No.July, pp.101-6.

Bateson J. (2002), "Consumer performance and quality in services", Managing Service Quality, Vol. 12 No.4, pp.206-9.

Baumgartner, H., Homburg, C. (1996), "Applications of structural equation modeling in marketing and consumer research: a review", International Journal of Research in Marketing, Vol. 13 pp.139-61.

Bentler, P. (2001), "Structural equations modeling - structural equations modeling and statements regarding causality", Journal of Consumer Psychology, Vol. 19 No.1/2, pp.84.

Bettencourt, L.A. (1997), "Customer voluntary performance: customers as partners in service delivery", Journal of Retailing, Vol. 73 No.3, pp.383-406. 
Bitner, M.J., Faranda, W.T., Hubert, A.R., Zeithaml, V.A. (1997), "Customer contributions and roles in service delivery", International Journal of Service Industry Management, Vol. 8 No.3, pp.193-205.

Bogler, R., Somech, A. (2002), "Motives to study and socialization tactics among university students", The Journal of Social Psychology, Vol. 142 No.2, pp.233-48.

Cermak, D.S.P., File, K.M., Prince, A.R. (1994), "Customer participation in service specification and delivery", Journal of Applied Business Research, Vol. 10 No.2, available at , http://search.global. epnet.com (EBSCO Host’s Business Source Premier database).

Claycomb, C., Lengnick-Hall, C.A., Inks, L.W. (2001), "The customer as a productive resource: a pilot study and strategic implications", Journal of Business Strategies, Vol. 18 No.1, pp.47-69.

Cook, A., Leckey, J. (1999), "Do expectations meet reality? A survey of changes in firstyear student opinion", Journal of Further and Higher Education, Vol. 23 No.2, pp.15771.

Cronin, J.J., Brady, M.K., Hult, G.T. (2000), "Assessing the effects of quality, value, and customer satisfaction on consumer behavioral intentions in service environments", Journal of Retailing, Vol. 76 No.2, pp.193-218.

Driscoll, C., Wicks, D. (1998), "The customer-driven approach in business education: a possible danger?", Journal of Education for Business, No.September/October, pp.58-61.

Fassinger, P.A. (1995), "Understanding classroom interaction: students' and professors' contributions to students' silence", Journal of Higher Education, Vol. 66 No.1, pp.82-96.

Feldman, D.C. (1976), "A contingency theory of socialization", Administrative Science Quarterly, Vol. 21 No.September, pp.433-50.

Fritschner, L.M. (2000), "Inside the undergraduate college classroom: faculty and students differ on the meaning of student participation", Journal of Higher Education, Vol. 71 No.3, pp.342-62.

Govender, K.K. (1998), "Managing service quality by managing the service encounter: the effects of organizational socialization strategies", University of Cape Town, Cape Town, unpublished DPhil thesis, Uninversity of Cape Town, Cape Town.

Hennig-Thurau, T., Langer, M.F., Hansen, U. (2001), "Modeling and managing student loyalty: an approach based on the concept of relationship quality", Journal of Service Research, Vol. 3 No.4, pp.331-44. 
Hill, F.M. (1995), "Managing service quality in higher education: the role of the student as primary consumer", Quality Assurance in Education, Vol. 3 No.3, pp.10-21.

Hoffman, K.D., Kelley, S.W. (1991), "The educational service encounter: the socialization of students", Journal of Marketing Education, No.Summer, pp.67-77.

Howard, J.R., Henney, A.L. (1998), Journal of Higher Education, Vol. 69 No.4, pp.384405.

Johnston, C. (2001), Higher Education Research and Development, Vol. 20 No.2, pp.169-84.

Karns, G.L. (1993), "Marketing student perceptions of learning activities: structure, preferences and effectiveness", Journal of Marketing Education, No.Spring, pp.3-10.

Kelley, S.W., Donnelly, J.H., Skinner, S.J. (1990), "Customer participation in service production and delivery", Journal of Retailing, Vol. 66 No.3, pp.315-35.

Kelley, S.W., Skinner, S.J., Donnelly, J.H. (1992), "Organizational socialization of service customers", Journal of Business Research, Vol. 25 pp.197-214.

Kellogg, D.L., Youngdahl, W.E., Bowen, D.E. (1997), "On the relationship between customer participation and satisfaction: two frameworks", International Journal of Service Industry Management, Vol. 8 No.3, pp.206-19.

Lengnick-Hall, C.A. (1996), "Customer contributions to quality: a different view of the customer-oriented firm", Academy of Management Review, Vol. 21 No.3, pp.791-824.

Lengnick-Hall, C.A., Claycomb, V., Inks, L.W. (2000), "From recipient to contributor: examining customer roles and experienced outcomes", European Journal of Marketing, Vol. 34 No.3-4, pp.359-83.

Lizzio, A., Wilson, K., Simons, R. (2002), "University students’ perceptions of the learning environment and academic outcomes: implications for theory and practice", Studies in Higher Education, Vol. 27 No.1, pp.27-52.

Lovelock, C.H., Young, R.F. (1979), "Look to customers to increase productivity", Harvard Business Review, Vol. 57 No.May/June, pp.168-78.

Mazzarol, T., Soutar, G.N. (1999), "Sustainable competitive advantage for educational institutions: a suggested model", International Journal of Educational Management, Vol. 13 No.6, pp.287-300.

Mills, P.K., Morris, J.H. (1986), "Clients as 'partial' employees of service organizations: role development in client participation", Academy of Management Review, Vol. 11 No.4, pp.726-35. 
Morgan, R.M., Hunt, S.D. (1994), "The commitment-trust theory of relationship marketing", Journal of Marketing, Vol. 58 No.July, pp.20-38.

Myers, S.A., Rocca, K.A. (2001), "Perceived instructor argumentativeness and verbal aggressiveness in the college classroom: effects on student perceptions of climate, apprehension, and state motivation", Western Journal of Communication, Vol. 65 No.2, pp.113-37.

Neemann, J., Harter, S. (1986), Self-Perception Profile for College Students, University of Denver Press, Denver, CO.

Neer, M.R. (1987), "The development of an instrument to measure classroom apprehension", Communication Education, Vol. 36 No.April, pp.154-66.

Netemeyer, R. (2001), "Structural equations modeling - structural equations modeling and statements regarding causality", Journal of Consumer Psychology, Vol. 19 No. 1/2, pp.83-4.

Niehoff, B.P., Turnley, W.H., Yen, H.J.R., Sheu, C. (2001), "Exploring cultural differences in classroom expectations of students from the United States and Taiwan", Journal of Education for Business, No.May/June, pp.289-93.

Nunn, C.E. (1996), "Discussion in the college classroom: triangulating observational and survey results", Journal of Higher Education, Vol. 67 No.3, pp.243-66.

Palihawadana, D., Holmes, G. (1999), "Modelling module evaluation in marketing education", Quality Assurance in Education, Vol. 7 No.1, pp.41-6.

Pintrich, P.R., Smith, D.A.F. (1993), "Reliability and predictive validity of the motivated strategies for learning questionnaire (MSLQ)", Educational and Psychological Measurement, http://search.global.epnet.com, Vol. 53 No.3, available at: http://search.global.epnet.com (EBSCO Host's Academic Search Premier database).

Pitkethly, A., Prosser, M. (2001), "The first-year experience project: a model for university-wide change", Higher Education Research and Development, Vol. 20 No.2, pp.185-98.

Ramsden, P. (1991), "A performance indicator of teaching quality in higher education: the course experience questionnaire", Studies in Higher Education, http://search.global.epnet.com, Vol. 16 No.2, available at: http://search.global.epnet.com (EBSCO Host’s Academic Search Premier database).

Rizzo, J.R., House, R.J., Lirtzman, S.E. (1970), "Role conflict and ambiguity in complex organizations", Administrative Science Quarterly, Vol. 15 No.2, pp.150-63. 
Rodie, A.R., Kleine, S.S. (2000), "Customer participation in services production and delivery", in Swartz, T.A., Iacobucci, D. (Eds),Handbook of Services Marketing and Management, Sage, Thousand Oaks, CA, pp.111-25.

Rosenfeld, L.B., Jarrard, M.W. (1985), "The effects of perceived sexism in female and male college professors on students' descriptions of classroom climate", Communication Education, Vol. 34 No.July, pp.205-13.

Sanders, P., Stevenson, K., King, M., Coates, D. (2000), "University students' expectations of teaching", Studies in Higher Education, Vol. 25 No.3, pp.310-23.

Schneider, B., Bowen, D.E. (1995), Winning the Service Game, Harvard Business School Press, Boston, MA.

Schwartzman, R. (1995), "Are students customers? The metaphoric mismatch between management and education", Education, Vol. 116 No. 2, available at: http://infotrac.galegroup.com/menu (Infotrac's Expanded Academic ASAP database).

Scott, S.V. (1999), "The academic as service provider: is the customer 'always right'?", Journal of Higher Education Policy and Management, Vol. 21 No.2, pp.193-202.

Solomon, M.R., Surprenant, C., Czepiel, J.A., Gutman, E.G. (1985), "A role theory perspective on dyadic interactions: the service encounter", Journal of Marketing, Vol. 49 No.Winter, pp.99-111.

Steenkamp, J.E.M., Baumgartner, H. (2000), "On the use of structural equation models for marketing modelling", International Journal of Research in Marketing, Vol. 17 pp.195-202.

Taylor, P.G. (2000), "Changing expectations: preparing students for flexible learning", The International Journal for Academic Development, Vol. 5 No.2, pp.107-15.

Vallerand, R.J., Pelletier, L.G., Blais, M.R., Brière, N.M., Senécal, C., Vallières, E.F. (1992), "The academic motivation scale: a measure of intrinsic, extrinsic and amotivation in education", Educational and Psychological Measurement, Vol. 52 No.4, pp.1003-17.

Wetzels, M., De Ruyter, K., Van Birgelen, M. (1998), "Marketing service relationships: the role of commitment", Journal of Business \& Industrial Marketing, Vol. 13 No.4/5, pp.406-23.

Wilson, K.L., Lizzio, A. (1997), "The development, validation and application of the course experience questionnaire", Studies in Higher Education, Vol. 22 No.1, available at: http://search.global.epnet.com (EBSCO Host’s Academic Search Premier database). 
Wright, L.K., Bitner, M.J., Zeithaml, V.A. (1994), "Paradigm shifts in business education: using active learning to deliver services-marketing content", Journal of Marketing Education, No.Fall, pp.5-19.

Zeithaml, V.A., Bitner, M.J. (1996), Services Marketing, McGraw-Hill, Singapore. 